\title{
TRANSCRIPTION FACTOR PROTEIN EXPRESSION PATTERNS BY NEURAL OR NEURONAL PROGENITOR CELLS OF ADULT MONKEY SUBVENTRICULAR ZONE
}

\author{
A. B. TONCHEV, ${ }^{a, b}$ T. YAMASHIMA, ${ }^{a *} K$. SAWAMOTO ${ }^{c, d}$ \\ AND H. OKANO \\ aDepartment of Restorative Neurosurgery, Division of Neuroscience, \\ Kanazawa University Graduate School of Medical Science, Takara- \\ machi 13-1, Kanazawa 920-8641, Japan \\ ${ }^{b}$ Division of Cell Biology, Department of Forensic Medicine, Varna \\ University of Medicine, 55 Marin Drinov str, BG-9002 Varna, Bulgaria \\ ${ }^{c}$ Bridgestone Laboratory of Developmental and Regenerative Neuro- \\ biology, Keio University School of Medicine, Tokyo, Japan \\ ${ }^{d}$ Department of Physiology, Keio University School of Medicine, Tokyo, \\ Japan
}

\begin{abstract}
The anterior subventricular zone of the adult mammalian brain contains progenitor cells which are upregulated after cerebral ischemia. We have previously reported that while a part of the progenitors residing in adult monkey anterior subventricular zone travels to the olfactory bulb, many of these cells sustain location in the anterior subventricular zone for months after injury, exhibiting a phenotype of either neural or neuronal precursors. Here we show that ischemia increased the numbers of anterior subventricular zone progenitor cells expressing developmentally regulated transcription factors including Pax6 (paired-box 6), Emx2 (empty spiracles-homeobox 2), Sox 1-3 (sex determining region Y-box 1-3), Ngn1 (neurogenin 1), Dlx1,5 (distalless-homeobox 1,5), Olig1,3 (oligodendrocyte lineage gene 1,3) and Nkx2.2 (Nk-box 2.2), as compared with control brains. Analysis of transcription factor protein expression by sustained neural or neuronal precursors in anterior subventricular zone revealed that these two cell types were positive for characteristic sets of transcription factors. The proteins Pax6, Emx2, Sox2,3 and Olig1 were predominantly localized to dividing neural precursors while the factors Sox1, Ngn1, DIx1,5, Olig2 and Nkx2.2 were mainly expressed by neuronal precursors. Further, differences between monkeys and non-primate mammals emerged, related to expression patterns of Pax6, Olig2 and DIx2. Our results suggest that a complex network of developmental signals might be involved in the specification of primate progenitor cells. () 2006 Published by Elsevier Ltd on behalf of IBRO.
\end{abstract}

Key words: cerebral ischemia, primate, adult neurogenesis, cell fate, developmental signal.

*Corresponding author. Tel: +81-76-265-2381; fax: +81-76-234-4264. E-mail address: yamashim@med.kanazawa-u.ac.jp (T. Yamashima). Abbreviations: BrdU, 5-bromo-2'-deoxyuridine; CNP, 2', 3'-cyclic nucleotide 3'-phosphodiesterase; Dlx, distalless-homeobox; Emx, empty spiracles-homeobox; GFAP, glial fibrillary acidic protein; Ngn, neurogenin; Nkx, Nk-box; Olig, oligodendrocyte lineage gene; Pax, pairedbox; Sox, sex determining region Y-box; SVZa, anterior subventricular zone; TRITC, tetramethylrhodamine isothiocyanate.

$0306-4522 / 06 \$ 30.00+0.00$ @ 2006 Published by Elsevier Ltd on behalf of IBRO doi:10.1016/j.neuroscience.2006.01.053
The subventricular zone of the anterior horn of the lateral ventricle (SVZa) in the brain of adult mammals contains multipotent neural progenitor cells which are a subject of intensive research, predominantly using rodent models (reviewed by Gage, 2000; Okano 2002). Although studied less extensively in adult primates, SVZa precursor cells were documented also at the primate level, in vitro (Pincus et al., 1998; Roy et al., 2000) and in vivo (Kornack and Rakic, 2001; Pencea et al., 2001). Cerebral ischemia increases the proliferation of the precursor cells residing in SVZa, in both focal (Jin et al., 2001; Zhang et al., 2001; Arvidsson et al., 2002; Parent et al., 2002) and global (Iwai et al., 2003) rodent models. Recently, we confirmed the preservation of this phenomenon in primates by labeling precursor cells in adult macaque monkey brains with the thymidine analog 5-bromo-2'-deoxyuridine (BrdU). We found that the proliferation of monkey SVZa progenitors peaked early after ischemia, and that while most of these cells were destined for the olfactory bulb, some precursors retained an immature phenotype and location in SVZa for months after injury (Tonchev et al., 2005). A similar phenomenon of sustained progenitor existence in SVZa had been previously described in developing monkey brain (Ourednik et al., 2001), but the molecular signals involved in this precursor cell retention as well as in the overall regulation of primate $S V Z a$ progenitors remain unknown.

A central role in the regulation of neural development is played by families of region- and cell type-selective transcription factors that determine fundamental decisions regarding the behavior and fate of selective progenitor cell populations in the embryonic brain (reviewed by Monuki and Walsh, 2001; Shirasaki and Pfaff, 2002; Schuurmans and Guillemot, 2002). Expression of several of these developmental signals has been shown in adult rodent SVZa precursors, including paired-box (Pax) 6 (Heins et al., 2002; Hack et al., 2004), empty spiracles-homeobox (Emx) 2 (Galli et al., 2002), distalless-homeobox (DIx) 2 (Doetsch et al., 2002), sex determining region Y-box (Sox) 2 (Ferri et al., 2004; Komitova and Eriksson, 2004), and oligodendrocyte lineage gene (Olig) 2 (Hack et al., 2004). At present, however, little is known of transcription factor expression by progenitor cells in adult primate SVZa.

In the present study, we investigated whether BrdUpositive $\left(\mathrm{BrdU}^{+}\right)$progenitor cells in adult monkey SVZa express developmentally-regulated transcription factors, under normal conditions or after ischemia. We combined BrdU labeling at both short- and long-term intervals after ischemia with immunostaining for Ki67 to identify progenitors in active phases of cell cycle, or with markers of 


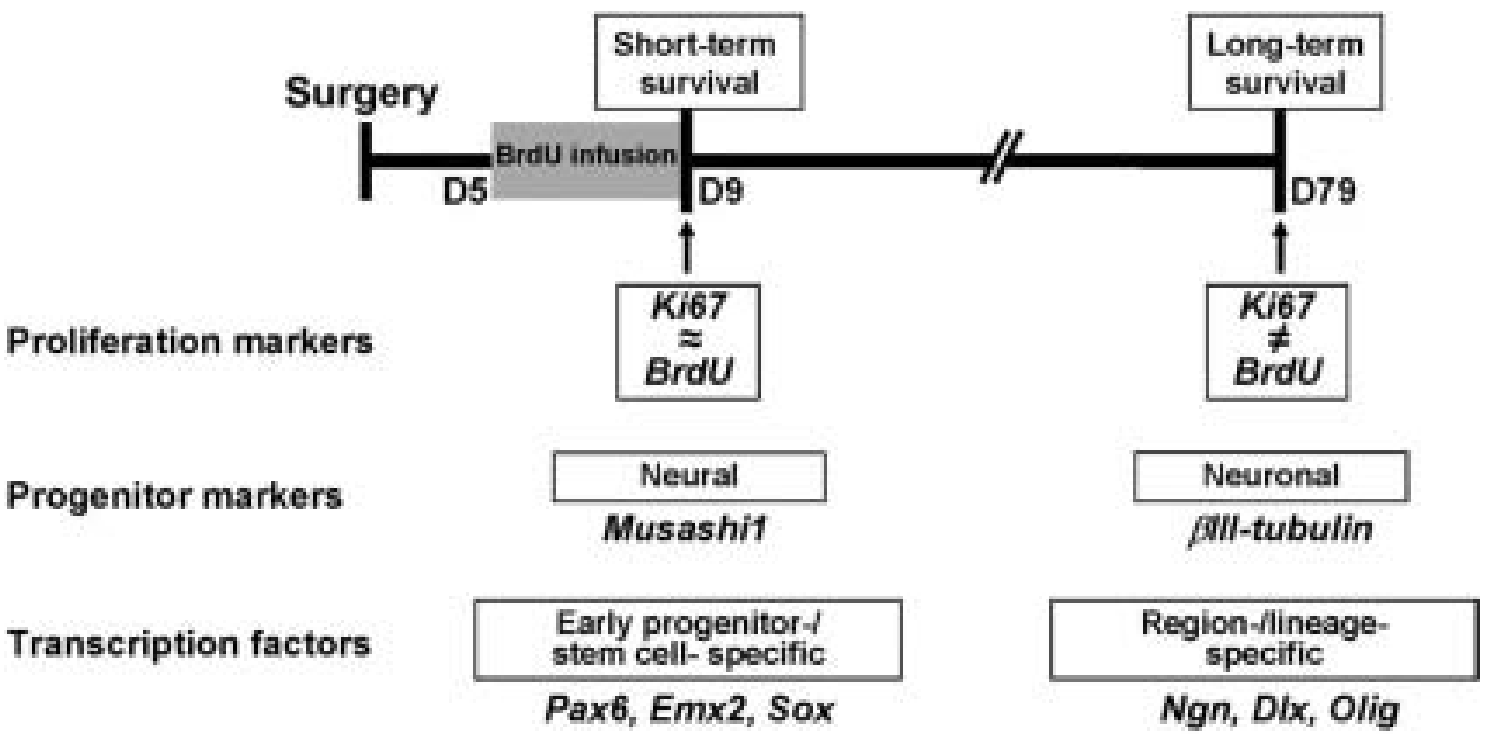

Fig. 1. Schematic presentation of BrdU/Ki67 paradigm and the investigation of transcription factor expression by progenitor cells in SVZa. BrdU infusion (gray bar) was performed between days 5-9 (D5-D9) after surgery, and the fate of BrdU ${ }^{+}$cells in SVZa was investigated on D9 (short-term interval) or at long-term intervals (D23, D44 and D79; D23 and D44 are omitted for clarity). As Ki67 selectively labels the proliferating cells at time of animal kill (arrows), at the D9 time-point almost all $\mathrm{BrdU}^{+}$cells are also $\mathrm{Ki}^{+} 7^{+}$, while at the long-term intervals after surgery only few BrdU ${ }^{+}$are co-labeled by Ki67. Cellular phenotypes characterized by their positivity for BrdU/Ki67 and Musashi1//III-tubulin (neural/neuronal) were investigated for putative expression of either early- or lineage-selective transcriptional regulators of embryonic brain development.

neural (Musashi1; Sakakibara et al., 1996; Sakakibara and Okano, 1997; Kaneko et al., 2000) or neuronal ( $\beta$ III-tubulin; Pencea et al., 2001) progenitors to discern which is the cell type expressing a certain transcription factor (Fig. 1). Transcription factors targeted in our study were selected based on their expression by precursor cells in embryonic vertebrate telencephalon. We first explored markers of early multipotential stem/progenitor cells: Pax6 (Muzio et al., 2002), Emx2 (Heins et al., 2001), and Sox1-3 (Bylund et al., 2003). We then investigated transcription factors which are known to be specific for region- or lineage-restricted forebrain precursors: dorsal telencephalic markers such as neurogenin (Ngn) proteins (Schuurmans and Guillemot, 2002; Schuurmans et al., 2004), and ventral telencephalic markers such as DIx (Anderson et al., 1997; Letinic et al., 2002; Stenman et al., 2003; Perera et al., 2004) and Olig (Schuurmans and Guillemot, 2002; Rowitch, 2004) proteins (Fig. 1). Our results suggest that some of these transcriptional regulators are expressed by adult primate SVZa progenitor cells and thus may be involved in their regulation.

\section{EXPERIMENTAL PROCEDURES}

\section{Monkeys}

Animal experiments were performed under the guidelines of the Animal Care and Ethics Committee of Kanazawa University, and the NIH Guide for the Care and Use of Laboratory Animals. Throughout the experiments, all efforts were made to minimize the number of animals used, and their suffering. Sexually mature female Japanese monkeys (Macaca fuscata) $(n=14)$ were bred in air-conditioned cages, and were allowed free daily access to food and water. Transient global cerebral ischemia was performed under general inhalation anesthesia with artificial ventilation as previously described (Yamashima, 2000; Yamashima et al., 1998; Tonchev et al., 2005). Briefly, after resecting the sternum, the innominate and left subclavian arteries were transiently clipped for $20 \mathrm{~min}$. The effectiveness of clipping was demonstrated by an almost complete absence $(0.5 \pm 1.0 \mathrm{ml} / 100 \mathrm{~g}$ brain $/ \mathrm{min})$ of cerebral blood flow being monitored by laser Doppler (Vasamedics, St. Paul, MN, USA). Ischemia was performed to eight macaques, while six macaques underwent sham surgery (executed by opening the chest without vessel clipping). All monkeys received five daily injections of $100 \mathrm{mg} / \mathrm{kg}$ i.v. of BrdU (Sigma-Aldrich Japan K.K., Tokyo, Japan), performed on days 5-9 after surgery. Respective animals were then killed on day $9(n=2)$, day $23(n=2)$, day 44 $(n=2)$ and day $79(n=2)$ after ischemia or on day $9(n=2)$, day 23 $(n=2)$ and day $44(n=2)$ after the sham operation (Tonchev et al., 2005).

\section{Tissue processing}

The monkeys were killed by intracardial perfusion with $4 \%$ paraformaldehyde under general anesthesia. The brains were removed, and tissue blocks (ac $+7 \mathrm{~mm}$ anteriorly to ac $+1 \mathrm{~mm}$ posteriorly) were cryoprotected in sucrose, and frozen in O.C.T. medium (Tissue-Tek, Sakura Finetech Co, Tokyo, Japan), and serially cut into $40-\mu \mathrm{m}$ thick coronal sections. All stainings were performed on free-floating sections. To reveal BrdU incorporated into the cells, DNA was denatured by treatment with formamide and $\mathrm{HCl}$ as described (Eriksson et al., 1998; Tonchev et al., 2003), followed by application of mouse anti-BrdU (1:100, Becton Dickinson, San Jose, CA, USA) or rat anti-BrdU (1:100, Harlan SeraLaboratory, Loughborough, UK) antibodies. We used the following antibodies for phenotypic markers: mouse anti-Ki67 (1:50, Novocastra, Newcastle, UK), rat anti-Musashi1 (1:100, Kaneko et al., 2000), rabbit anti-Musashi1 (1:200, Chemicon, Temecula, CA, USA), rabbit or mouse anti-Nestin (1:200, Chemicon), mouse anti-NeuN (1:100, Chemicon), rabbit or mouse anti- $\beta$-tubulin class III (1:400, Covance, Richmond, CA, USA), goat anti-Doublecortin (1:200; Santa Cruz Inc., Santa Cruz, CA, USA), mouse anti-2', $3^{\prime}$ cyclic nucleotide $3^{\prime}$-phosphodiesterase (CNP) (1:400; Chemicon), 
and rabbit anti-glial fibrillary acidic protein (GFAP) (1:400, Sigma). The following rabbit polyclonal antibodies against transcription factors were obtained from Chemicon: Emx2 (1:400), Ngn1 (1: 2000), Ngn2 (1:1500), Ngn3 (1:100-1:1000), Dlx1 (1:500), Dlx2 (1:200), DIx5 (1:1000), Sox1 (1:200), Sox2 (1:200), Sox3 (1:200), Olig1 (1:1000), Olig3 (1:300), Nkx2.2 (1:400). The rabbit Pax6 antibody (1:200) was from Covance, and the rabbit anti-Olig2 antibody was a gift from Hirohide Takebayashi (National Institute for Physiological Sciences, Okazaki, Japan).

The primary antibodies were revealed by appropriate secondary antibodies conjugated to AlexaFluor 488, 546, or 633 (Molecular Probes, Eugene, OR, USA), tetramethylrhodamine isothiocyanate (TRITC; Jackson Immunoresearch, West Grove, PA, USA), or to biotin for immunoperoxidase labeling (1:30-1:100; Vector ABC kit, Vector Laboratories, Burlingame, CA, USA). For double- and triple-staining, the respective primary antibodies were from different species, and were applied sequentially to minimize the probability for cross-reactivity. Negative control experiments were performed by omitting the primary antibody and these revealed no positive staining.

\section{Image analysis}

Double- and triple-labeling to determine the expression of transcription factors by BrdU-labeled cells or cells labeled for particular phenotypic markers was evaluated using confocal laser scanning microscopy (LSM 510, Carl Zeiss, Tokyo, Japan). Alexa Fluor 488 was appointed in the green channel, TRITC or Alexa Fluor 546 , in the red channel, and Alexa Flour 633, in the blue channel. Each fluorochrome was scanned separately and sequentially to minimize the probability of signal transfer among channels. $Z$ sectioning at $0.5-1 \mu \mathrm{m}$ intervals was performed and optical stacks of at least 20 images were used for analysis. Digital three-dimensional reconstructions were created by the Zeiss LSM software version 2.3. Within each animal group, at least 150 cells positive for BrdU or a phenotypic marker were sampled for co-expression with respective transcription factors. The absolute numbers of transcription factor/BrdU double-positive cells were determined by multiplying the corresponding fractions with the total numbers of $\mathrm{BrdU}^{+}$cells evaluated on every 12th section stained by the peroxidase method within grids of $800 \mu \mathrm{m} \times 100 \mu \mathrm{m}$ placed in the dorsal, ventral, and striatal aspects of SVZa (see Fig. 2A) as previously described (Tonchev et al., 2005). Numbers and percentages were averaged to obtain a mean density value for each transcription factor/animal group.

\section{Statistical analysis}

For comparing percentages of cells expressing certain transcription factor, we applied nonparametric tests (Mann-Whitney $U$ test and Kruskal-Wallis test) or one-way ANOVA followed by TukeyKramer's post hoc comparisons. Data were expressed as means \pm S.E.M. Differences were considered significant when $P<0.05$.

\section{RESULTS}

\section{Expression of Pax6, Emx2 and Sox proteins by SVZa progenitors}

Immunohistochemical staining for the transcription factors Pax6, Emx2, and Sox1-3 revealed numerous positive cells, frequently in clusters, located along the walls of the anterior horn of the lateral ventricle (Fig. 2A, arrows), the zone that contains proliferating $\left(\mathrm{BrdU}^{+}\right)$precursor cells in the adult mammalian brain (Fig. 2A, arrowheads). At the early post-BrdU time-point (day 9 after surgery, $2 \mathrm{~h}$ after the last BrdU injection), most (75-85\%) $\mathrm{BrdU}^{+}$cells in
SVZa co-expressed Pax6 (Fig. 2B, 2F1), Emx2 (Fig. 2C, $2 \mathrm{~F} 2$ ) and Sox2,3 (Fig. 2F4, F5). The Sox $1^{+} / \mathrm{BrdU}^{+}$cells composed about half of the $\mathrm{BrdU}^{+}$cells (Fig. 2D, 2F3). At a late post-BrdU survival time-point (day 44 after surgery, 5 weeks after the last $\mathrm{BrdU}$ injection), many of the $\mathrm{BrdU}^{+}$ cells that had retained their presence in SVZa revealed negativity for the transcription factors (Fig. 2E, arrows). The percentage of $\mathrm{BrdU}^{+}$cells expressing Pax6, Emx2 or Sox2,3 decreased with a statistical significance $(P<0.05$, Kruskal-Wallis test), while the Sox $1 / \mathrm{BrdU}$ co-labeling sustained its value (Fig. 2F). While no statistically significant difference was found between sham-operated and ischemic brains with respect to the percentage of $\mathrm{BrdU}^{+}$cells expressing the five transcription factors (Fig. $2 \mathrm{~F}$ ), the absolute numbers of BrdU/transcription factor double-positive cells in postischemic SVZa was significantly greater than in the controls (Fig. 2G).

To investigate the progenitor cell type(s) expressing Pax6, Emx2 and Sox1-3, we performed co-labeling with Musashi1, a marker of neural progenitor cells (Kaneko et al., 2000), and with $\beta$ III-tubulin or Doublecortin, markers of progenitors committed to neuronal lineage (neuronal progenitors) (Pencea et al., 2001; Gleeson et al., 1999). We observed that Pax6 (Fig. 3A, 3H1), Emx2 (Fig. 3B, 3H2) and Sox2,3 (Fig. 3C, 3H3) co-stained exclusively with Musashi1 in both ischemic and sham-operated animals. Co-labeling with neuronal progenitor markers (Fig. 3D) was negligible for these four transcription factors $(<1 \%$ of the Pax6 $6^{+}$, Sox $2,3^{+}$cells, and $<5 \%$ of the Emx2 $2^{+}$cells). In contrast, Sox 1 co-labeled mostly with $\beta$ III-tubulin (Fig. 3F, $3 \mathrm{H} 4$ ), while less than $3 \%$ of the Sox $1^{+}$cells co-expressed Musashi1 (Fig. 3E, 3H4). The transcription factor-positive clusters remained negative for GFAP (Fig. 3G).

\section{Differential transcription factor expression by sustained proliferating progenitors}

We have previously documented the existence of longterm BrdU-retaining cells in SVZa that have incorporated BrdU early after ischemia and preserved an immature phenotype and location in SVZa for months after injury (Tonchev et al., 2005; see Fig. 1). Most of these $\mathrm{BrdU}^{+}$ cells expressed $\beta$ III-tubulin indicating neuronal differentiation, while a few were positive for Musashi1 and Ki67 suggesting they were neural progenitors in active phases of their cell cycle (Tonchev et al., 2005). We investigated whether BrdU/Ki67 double-positive cells co-express transcription factors at long-term time-points after ischemia/ BrdU. Triple-labeling for BrdU, Ki67 and the five transcription factors on postischemic days 44 or 79 (5 or 10 weeks after BrdU, respectively) revealed that the vast majority of the $\mathrm{BrdU}^{+} / \mathrm{Ki} 7^{+}$cells in SVZa were co-labeled for $\mathrm{Em} \times 2$ (Fig. 4A; 47 of $53 \mathrm{BrdU}^{+} / \mathrm{Ki}^{+} 7^{+}$cells), Pax6 (Fig. 4B; 43 of 51), Sox2 (Fig. 4C; 50 of 55) or Sox3 (51 of 57). In contrast, Sox1 expression was not found in $\mathrm{BrdU}^{+} / \mathrm{Ki} 67^{+}$ cells (Fig. 4D). Additional experiments provided direct evidence that the $\mathrm{Ki}^{+} 7^{+}$cells were Musashi1 ${ }^{+}$(Fig. 4E, arrowheads) but negative for $\beta$ III-tubulin (Fig. 4E, arrows), and that Musashi1 was expressed by sustained $\mathrm{BrdU}^{+} /$ Sox $3^{+}$cells (Fig. 4F), and similarly, by sustained $\mathrm{BrdU}^{+} /$ 

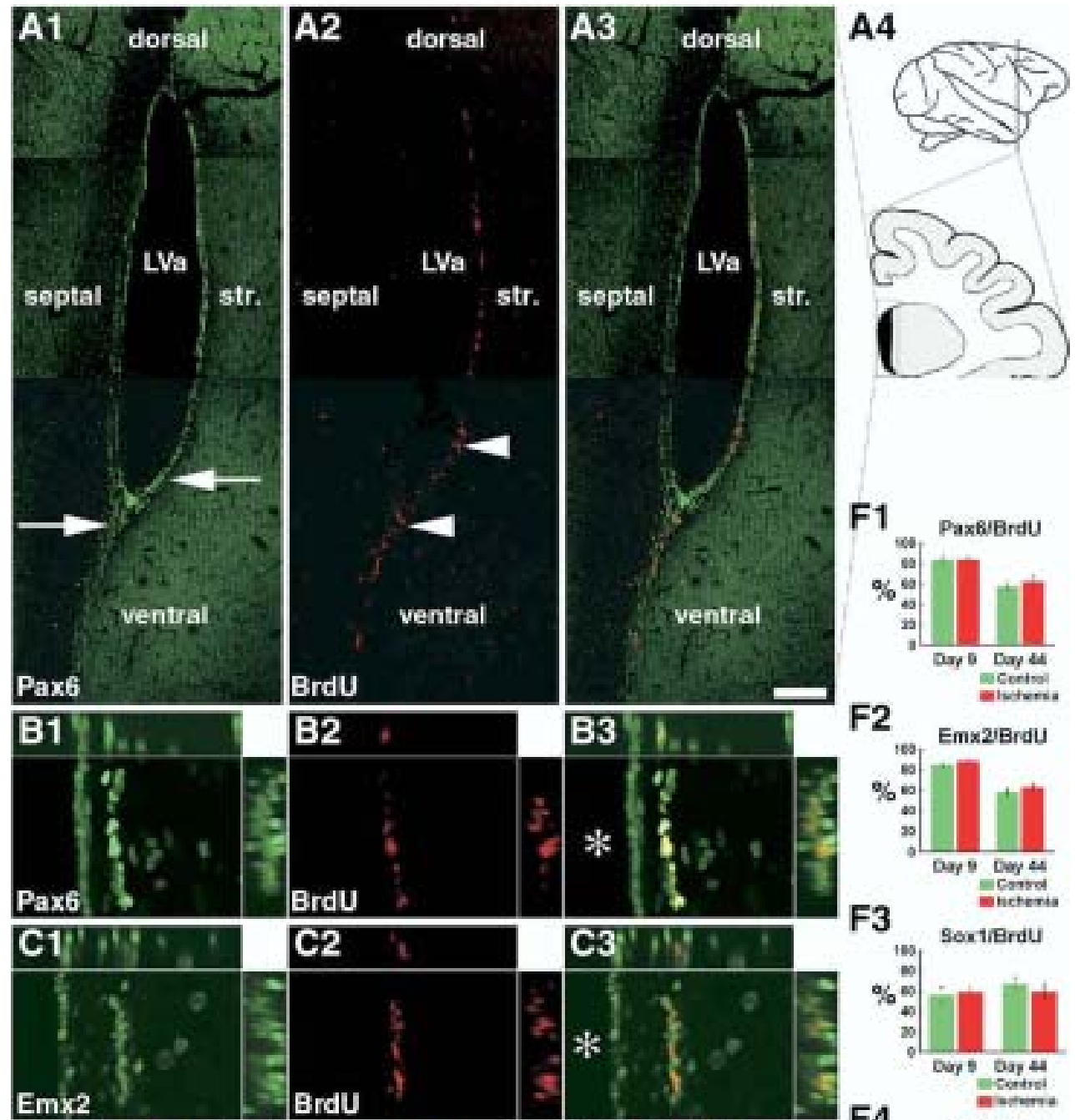

F2

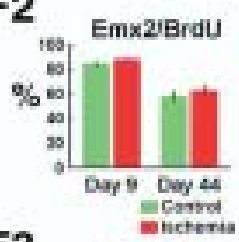

F3
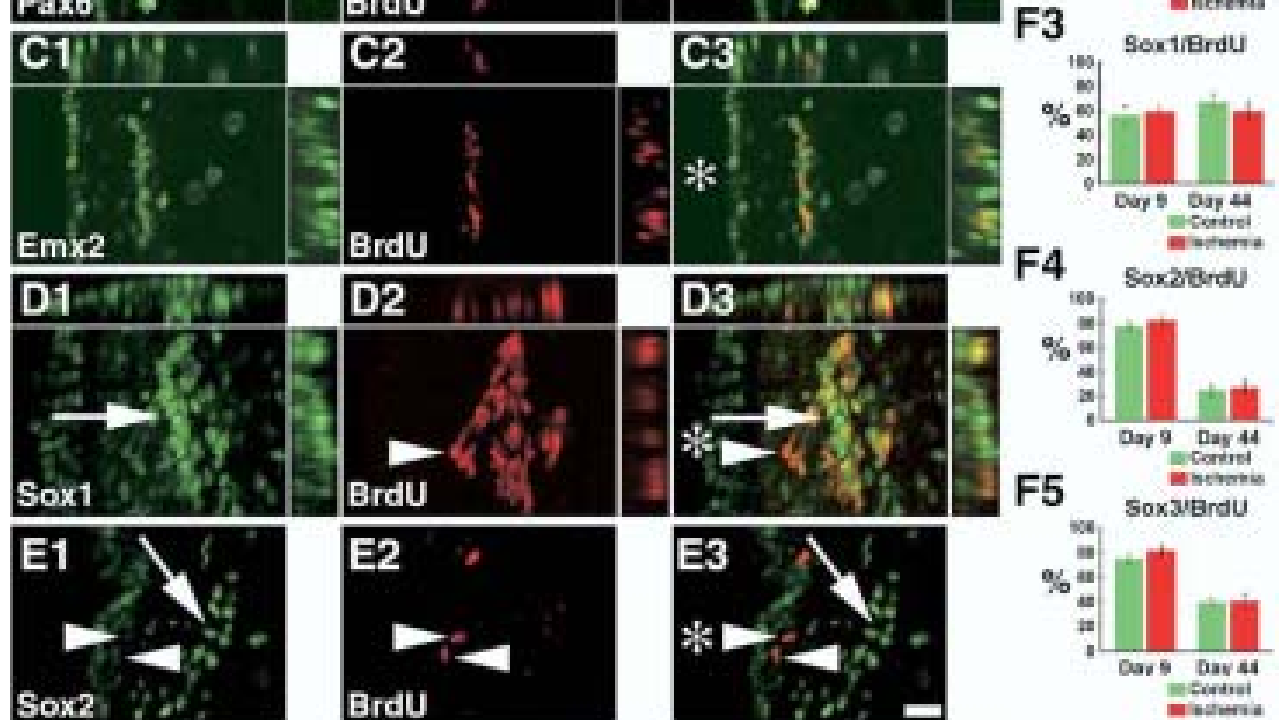

F4

Saxarentu
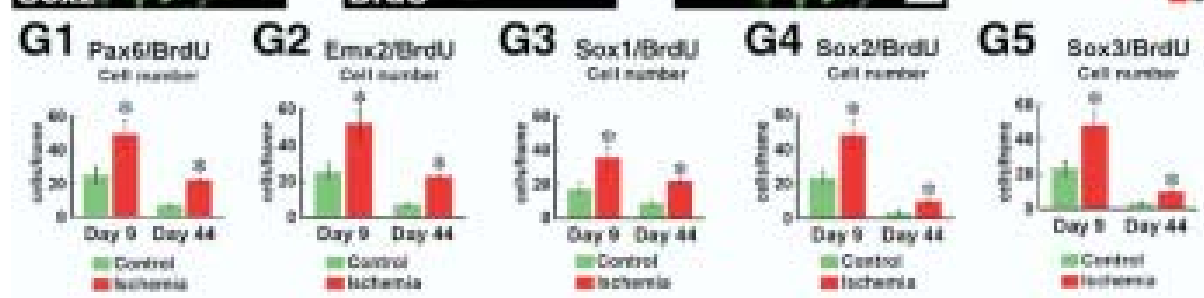

Fig. 2. Expression of Pax6, Emx2 and Sox proteins by BrdU + cells in monkey SVZa. (A) Low magnification micrographs showing the overall distribution of Pax6 (A1) and BrdU (A2) positive signals in SVZa, and overlay (A3). The position of the anterior horn of the lateral ventricle (LVa) sampled in A1-A3 is depicted on the schematic map (A4). Note that both $\mathrm{Pax}^{+}$cells (arrows) and $\mathrm{BrdU}^{+}$cells (arrowheads) are preferentially located along the walls of LVa, not in the parenchyma. The images are representative also for the other four transcription factors. Str., striatal SVZa. (B) High 
Sox2 ${ }^{+}, \mathrm{BrdU}^{+} / \mathrm{Pax}^{+}$and $\mathrm{BrdU}^{+} / \mathrm{Emx}^{+}$cells (data not shown).

\section{Expression of Ngn proteins by SVZa progenitors}

Double-labeling for BrdU and Ngn1 (Fig. 5A) or Ngn2 (Fig. 5B) revealed contrasting findings. The $\mathrm{Ngn}^{+} / \mathrm{BrdU}^{+}$cells comprised a significant proportion of the $\mathrm{BrdU}^{+}$cells $(60-$ $70 \%$ on day $9 ; 35-40 \%$ on day 44 ), while the $\mathrm{Ngn2}^{+}$/ $\mathrm{BrdU}^{+}$cells were few (less than $5 \%$ of the $\mathrm{BrdU}^{+}$cells on day 44) (Fig. 5C1, 5C2). The $\mathrm{Ngn}^{+} / \mathrm{BrdU}^{+}$cells were typically grouped within a larger $\mathrm{Ngn}^{+}{ }^{+}$cluster (Fig. 5A, box). The rare $\mathrm{Ngn}^{+} / \mathrm{BrdU}^{+}$cells were entangled in the $\mathrm{BrdU}^{+}$clusters (Fig. 5B4-5B6, arrows) as were some $\mathrm{Ngn} 2^{+} / \mathrm{BrdU}^{-}$cells (Fig. 5B4-5B6, arrowheads). No statistically significant difference was found between shamoperated and ischemic brains with respect to the percentage of $\mathrm{BrdU}^{+} / \mathrm{Ngn}^{+}$cells, while the absolute numbers of $\mathrm{BrdU}^{+} / \mathrm{Ngn}^{+}{ }^{+}$(but not $\mathrm{BrdU}^{+} / \mathrm{Ngn2}^{+}$) cells in postischemic SVZa were significantly greater than in the controls (Fig. 5C3, 5C4). A third member of the family, Ngn3, was not found to be expressed in SVZa in our experiments (data not shown).

Co-staining with progenitor cell markers also revealed differences between Ngn1 and Ngn2. Ngn1 and Musashi1 co-labeled extensively (Fig. 5D) forming large (more than 10 cells) double-labeled clusters, with the $\mathrm{Ngn}^{+} /$Musashi1 $^{+}$ cells comprising $70-75 \%$ of the $\mathrm{Ngn} 1^{+}$cells on day 9 (Fig. $5 \mathrm{H} 1$ ). In contrast, only a third of the $\mathrm{Ngn} 2^{+}$cells co-stained with Musashi1 (Fig. 5E, 5H1). Ngn $1^{+}$clusters smaller than the $\mathrm{Ngn} 1^{+} /$Mushashi $1^{+}$clusters (typically up to five cells) expressed $\beta$ III-tubulin (Fig. 5F, arrows), and Ngn1/ $\beta$ IIItubulin co-labeling increased at long-term time points (Fig. 5J1). In addition, $\mathrm{Ngn}^{+}{ }^{+}$clusters were closely associated with $\beta$ Ill-tubulin ${ }^{+}$aggregates (Fig. $5 \mathrm{~F}$, arrowheads), although most of the $\mathrm{Ngn}^{+}$cells themselves were negative for $\beta$ III-tubulin. Only single rare $\mathrm{Ngn} 2^{+}$cells co-labeled with $\beta$ III-tubulin (Fig. 5G, arrows). Ngn $1^{+}$cells expressed Ki67 on day 9 (Fig. $5 \mathrm{H}$ ), but not at long-term time points (Fig. 5I).

\section{Expression of DIx proteins by SVZa progenitors}

Double-labeling experiments with $\mathrm{BrdU}$ and antibodies against Dlx1,2,5 revealed that clusters positive for Dlx1 (Fig. 6A) and Dlx5 (Fig. 6C) extensively co-labeled with BrdU. In contrast, Dlx2/BrdU co-staining (Fig. 6B) was minimal $\left(<2 \%\right.$ of the $\mathrm{BrdU}^{+}$cells). The percentage of $\mathrm{BrdU}^{+}$cells double-stained for Dlx1 or DIx 5 was $70-75 \%$ on day 9 decreasing (with a statistical significance, $P<0.01$, Kruskal-Wallis test) to $35-40 \%$ on day 44 (Fig. $6 \mathrm{D} 1,6 \mathrm{D} 2)$. No statistically significant difference was found between sham-operated and ischemic brains $(P>0.05$, Kruskal-Wallis test). The absolute numbers of $\mathrm{BrdU}^{+} /$ $\mathrm{Dlx}^{+}$(Fig. 6D3) and $\mathrm{BrdU}^{+} / \mathrm{Dl} 5^{+}$(Fig. 6D4) cells in postischemic SVZa were significantly greater than in the controls.

Double-labeling for DIx1,5 and Musashi1 revealed that both $\mathrm{Dlx}^{+} /$Musashi1 $1^{+}$cells (Fig. 6E, arrows) and $\mathrm{Dlx}^{-} /$ Musashi $1^{+}$cells (Fig. 6E, arrowheads) were aggregated in a common cluster. Dlx1 did not co-label with Ki67 at longterm survival time-points (Fig. 6F), and neither did DIx2 nor Dlx5 (data not shown). The Dlx $1^{+} /$Musashi $1^{+}$and $\mathrm{Dl} \times 5^{+} /$ Musashi $1^{+}$cells were numerous (Fig. 6I), while only rare Dl $\times 2^{+} /$Musashi $1^{+}$cells were observed (data not shown). Both DIx1 and Dlx5 co-stained with $\beta$ III-tubulin (Fig. 5G, $5 \mathrm{I})$, and notably, with sustained neuronal progenitors $\left(\mathrm{BrdU}^{+} / \beta\right.$ III-tubulin ${ }^{+}$cells) at long-term survival time-points after BrdU (Fig. 5H). DIx2 did not co-label with $\beta$ Ill-tubulin or Doublecortin (data not shown).

\section{Expression of Olig proteins by SVZa progenitors}

Double-staining for BrdU and Olig1 or Olig3 demonstrated that the two transcription factors extensively co-labeled with BrdU on day 9 (Fig. 7A), while at long-term survival (day 44) the percentage of co-staining with BrdU significantly decreased (Fig. 7B, 7E1, 7E2). In contrast, Olig2 ${ }^{+}$ clusters (Fig. 7C, arrows) did not co-label with BrdU (Fig. $7 \mathrm{C}$, arrowheads), and only single weakly labeled Olig2 ${ }^{+}$ cells rarely co-stained with $\mathrm{BrdU}\left(<1 \%\right.$ of the $\mathrm{BrdU}^{+}$cells). We also investigated Nkx2.2, a factor that is also involved in the control of oligodendrogenesis in both embryonic and adult brain (Rowitch, 2004; Fancy et al., 2004). Similarly to Olig1,3, Nkx2.2 (Fig. 7D) extensively co-labeled with BrdU at short-term survival time-points, while at long-term survival (day 44) the percentage of co-staining with BrdU decreased (Fig. 7E3) with a statistical significance $(P<0.05$, Kruskal-Wallis test). The percentage of Nkx2.2/ BrdU co-labeling (45-50\%) was significantly higher than the percentage of Olig1/BrdU or Olig3/BrdU co-labeling $(10-15 \%) \quad(P<0.01$, Kruskal-Wallis test). The absolute numbers of $\mathrm{BrdU}^{+} /$Olig1 ${ }^{+}$(Fig. 7E4), BrdU ${ }^{+} / \mathrm{Olig}^{+}{ }^{+}$(Fig. 7E7) and $\mathrm{BrdU}^{+} / \mathrm{Nkx}^{+} 2^{+}$(Fig. 7E6) cells in postischemic SVZa were significantly greater than in the controls.

Dual immunohistochemical staining with Musashi1 resulted in co-labeling with Nkx2.2, Olig1 and Olig3 (Fig. 7F, $7 \mathrm{~J})$, but not with Olig2 (data not shown). On the other hand, Olig3 and Nkx2.2 (but not Olig1 or Olig2) co-stained with $\beta$ III-tubulin in SVZa (Fig. 7G, 7J), while Nkx2.2 and Olig2 co-labeled with the oligodendrocyte marker CNP (Braun et al., 1988) in the adjacent striatal parenchyma (Fig. 7H). At long-term survival time-points after BrdU Olig1 (but not

power view of Pax6 (B1) and BrdU (B2) double-staining on day 9, and overlay of the channels (B3). (C) Staining for Emx2 (C1) and BrdU (C2) on day 9 , and overlay (C3). (D) Staining for Sox1 (D1) and BrdU (D2), and overlay (D3), day 44. Note that while most cells within the cluster are double-positive (arrows), a few are Sox $1^{-} / \mathrm{BrdU}^{+}$(arrowheads). Staining of Sox 1 is representative also for Sox 2,3 on day 9 . Orthogonal projections in the $x$ and $y$ axes (right and top of each image in B-D) confirm co-labeling. (E) Sox2/BrdU double-staining on day 44 (long-term survival after surgery/BrdU). Many of the $\mathrm{BrdU}^{+}$cells (arrowheads) are not co-labeled by Sox2 (arrows). Image is representative also for Sox3. (F) Percentage of BrdU ${ }^{+}$cells co-labeled for Pax6 (F1), Emx2 (F2), Sox1 (F3), Sox2 (F4) or Sox3 (F5), at short-term (day 9) or long-term (day 44) survival after surgery/BrdU. (G) Absolute number of BrdU ${ }^{+}$cells co-labeled for Pax6 (G1), Emx2 (G2), Sox1 (G3), Sox2 (G4) or Sox3 (G5). * $P<0.05$ versus control. Scale bar=200 $\mu \mathrm{m}(\mathrm{A})$; $20 \mu \mathrm{m}(\mathrm{B}-\mathrm{E})$. Asterisk, lateral ventricle. 

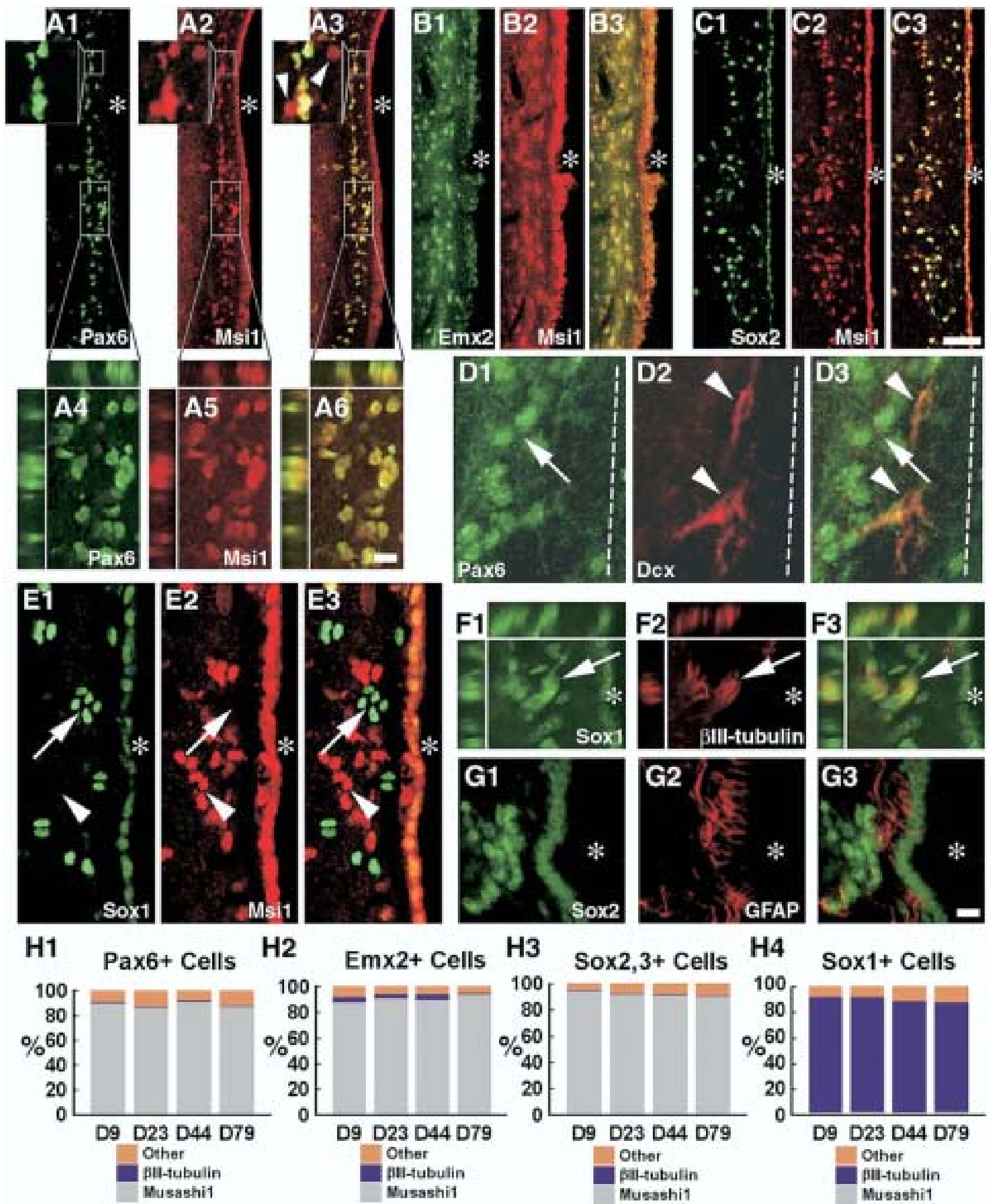

Fig. 3. Co-labeling of Pax6, Emx2 and Sox proteins with progenitor cell markers. (A) Double-staining for Pax6 (A1) and Musashi1 (Msi1, A2), and overlay (A3), on day 9. Two regions (depicted in frames) in the low magnification micrograph are shown in magnification in the insets. The upper inset demonstrates that despite extensive co-labeling, single-labeled cells were also observed (arrowheads). The lower inset (A4-A6) shows confirmation of double-staining by computer-generated orthogonal projections. (B) Double-staining for Emx2 (B1) and Musashi1 (B2), and overlay (B3), on day 9. (C) Double-staining for Sox2 (C1) and Musashi1 (C2), and overlay (C3), on day 44. (D) Double-staining for Pax6 (D1; a positive "doublet" is depicted 

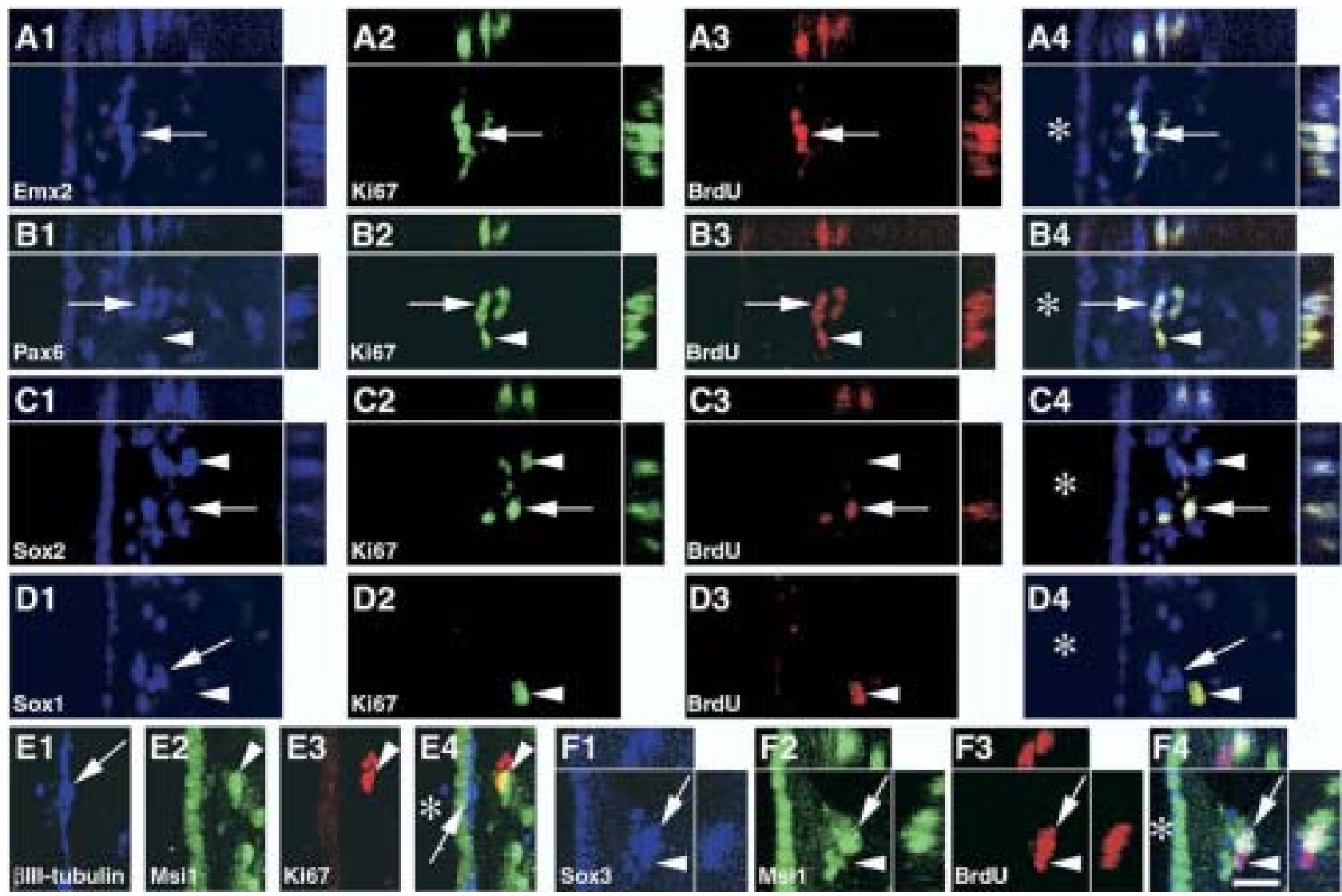

Fig. 4. Transcription factor expression by sustained proliferating progenitors at long-term survival time-points after BrdU. (A) Triple-labeling for Emx2 (A1), Ki67 (A2) and BrdU (A3), and overlay (A4), on day 79. Triple-labeled cells are depicted by an arrow. (B) Triple-labeling for Pax6 (B1), Ki67 (B2) and $\mathrm{BrdU}$ (B3), and overlay (B4), on day 79. Triple-labeled cells are depicted by an arrow, a Pax6 $6^{-} / \mathrm{Ki} 67^{+} / \mathrm{BrdU}^{+}$cell is shown by an arrowhead. (C) Triple-labeling for Sox2 (C1), Ki67 (C2) and BrdU (C3), and overlay (C4), on day 79. Triple-labeled cells are depicted by an arrow, a Sox $2^{+} / \mathrm{Ki6} 7^{+} /$ $\mathrm{BrdU}^{-}$cell is shown by an arrowhead. Sox2 staining is representative also for Sox3. (D) Triple-labeling for Sox1 (D1), Ki67 (D2) and BrdU (D3), and overlay (D4), on day 79. Note lack of Sox1 expression (arrow) by a Ki67 ${ }^{+} / \mathrm{BrdU}^{+}$cell (arrowhead). (E) Triple-labeling for $\beta$ III-tubulin (E1) Musashi1 (Msi1, E2), Ki67 (E3), and overlay (E4), on day 44. Ki67 co-labels with Msi1 (arrowheads), not with $\beta$ Ill-tubulin (arrows). (F) Triple-labeling for Sox3 $(\mathrm{F} 1)$, Musashi1 (F2) and BrdU (F3), and overlay (F4), on day 79. Triple-stained cells are depicted by arrows. Scale bar=20 $\mu \mathrm{m}$. Asterisk, lateral ventricle.

Olig2, Olig3 or Nkx2.2, data not shown) co-labeled with Ki67 (Fig. 6I).

\section{DISCUSSION}

Mechanisms that specify the fate of embryonic neural precursors might be at least in part recapitulated in the adult brain (Gotz, 2003; Alvarez-Buylla and Lim, 2004). This concept was supported by data in rodents showing that transcriptional regulators of embryonic precursors were also expressed by adult SVZa progenitors: Pax6 and Olig2 (Hack et al., 2004), Emx2 (Galli et al., 2002), Dlx2 (Doetsch et al., 2002), and Sox2 (Ferri et al., 2004; Komitova and Eriksson, 2004). We first report expression of developmentally-regulated transcription factors at protein level by SVZa progenitor cells of adult primate brain. Ischemia increased the absolute numbers of $\mathrm{BrdU}^{+}$cells expressing the proteins Pax6, Emx2, Sox1-3, Ngn1, Dlx1,5, Olig1,3, and Nkx2.2 as compared with controls (Fig. 8A). The decrease of BrdU/transcription factor co-labeled cells at long-term as compared with short-term time intervals reflects the global decrease of labeled progenitor cells in SVZa over time (Tonchev et al., 2005) as the precursor cells migrate away from SVZa toward the olfactory bulb. Notably, ischemia did not affect the percentage of BrdU/ transcription factor double-labeled cells as compared with controls. These data are compatible with our previous

by an arrow) and Doublecortin (DCX) (D2; arrowheads), and overlay (D3), on day 23. (E) Double-staining for Sox1 (E1, arrow depicts a positive cluster) and Musashi1 (E2; arrowhead), and overlay (E3), on day 44. (F) Double-staining for Sox1 (F1) and $\beta$ III-tubulin (F2), and overlay (F3), on day 44 (the cluster depicted by an arrow is reconstructed in the $x$ and $y$ axes, on left and top the image). (G) Double-staining for Sox2 (G1) and GFAP (G2), and overlay (G3), on day 9. (H) Percentages of Pax6 ${ }^{+}(\mathrm{H} 1), \mathrm{Emx}^{+}(\mathrm{H} 2)$, Sox2,3 $3^{+}(\mathrm{H} 3)$ and Sox1 $1^{+}(\mathrm{H} 4)$ cells co-expressing Musashi1 or $\beta I I I-t u b u l i n$ in the postischemic monkeys. Transcription factor-positive cells that were Musashi1-/ $\beta$ III-tubulin ${ }^{-}$are designated "other." Percentages in the control monkeys did not differ significantly from the postischemic ones. Scale bar $=50 \mu \mathrm{m}(A-C) ; 10 \mu \mathrm{m}(\mathrm{D}-\mathrm{G})$. Asterisk, lateral ventricle. 

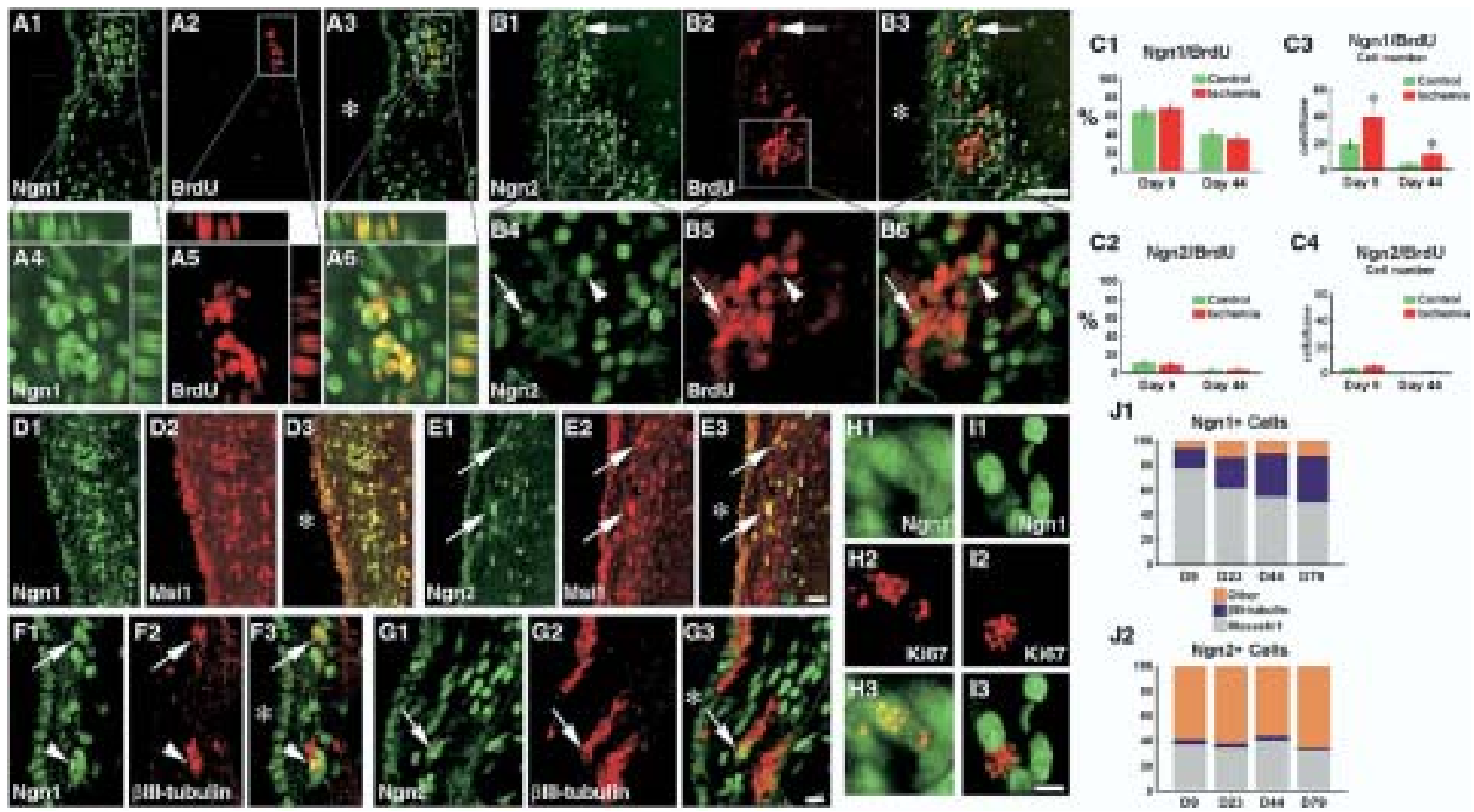

Fig. 5. Expression of Ngn proteins by SVZa progenitor cells. (A) Double-staining for Ngn1 (A1) and BrdU (A2), and overlay (A3), on day 9. The region depicted by a box is magnified in A4-A6 with orthogonal projections. (B) Double-staining for Ngn2 (B1) and BrdU (B2), and overlay (B3), on day 9. Double-labeled cells (arrow) are rare. The region depicted by a box is magnified in B4-B6 with orthogonal projections. Note a single Ngn2 ${ }^{+} / \mathrm{BrdU}^{+}$ cell (arrow) within the $\mathrm{BrdU}^{+}$cluster; a Ngn2 ${ }^{+} / \mathrm{BrdU}^{-}$cell (arrowhead) is entangled in the same aggregate. (C) Percentages (C1, C2) and absolute numbers (C3, C4) of $\mathrm{BrdU}^{+} \mathrm{Ngn}^{+}{ }^{+}(\mathrm{C} 1, \mathrm{C} 3)$ and $\mathrm{BrdU}^{+} / \mathrm{Ngn}^{+}$cells $(\mathrm{C} 2, \mathrm{C} 4) .{ }^{*} P<0.05$ versus control. (D) Double-staining for Ngn1 (D1) and Musashi1 (Msi1, D2), and overlay (D3), on day 9. Note extensive co-labeling of the two signals. (E) Double-staining for Ngn2 (E1) and Musashi1 (E2), and overlay (E3), on day 9. The Ngn2 ${ }^{+} /$Musashi $^{+}$cells (arrows) are rare. (F) Double-staining for Ngn1 (F1) and $\beta$ III-tubulin (F2), and overlay (F3), on day 23. A Ngn $1^{+}$"doublet" is double-labeled (arrow), and a single cell of an Ngn $1^{+}$cluster (arrowhead) expresses $\beta$ III-tubulin, while a neighboring $\beta$ III-tubulin ${ }^{+}$cell is negative for Ngn1. (G) Double-staining for Ngn2 (G1) and $\beta$ III-tubulin (G2), and overlay (G3), on day 44 . A single Ngn2 ${ }^{+}$cells is double-labeled (arrow). (H) Double-staining for Ngn1 (H1) and Ki67 (H2), and overlay (H3), on day 9. (I) Double-staining for Ngn1 (I1) and Ki67 (I2), and overlay (I3), on day 44. (J) Percentages of $\mathrm{Ngn}^{+}(\mathrm{J} 1)$ or $\mathrm{Ngn}^{+}(\mathrm{J} 2)$, cells co-expressing Musashi1 or $\beta$ III-tubulin in the postischemic monkeys. Transcription factor-positive cells that were Musashi1 ${ }^{-} / \beta / I$-tubulin ${ }^{-}$are designated "other." Percentages in the control monkeys did not differ significantly from the postischemic ones. Scale bar $=50 \mu \mathrm{m}(\mathrm{A}, \mathrm{B}) ; 20 \mu \mathrm{m}(\mathrm{D}, \mathrm{E}) ; 10 \mu \mathrm{m}(\mathrm{F}, \mathrm{G}) ; 5 \mu \mathrm{m}(\mathrm{H}, \mathrm{I})$. Asterisk, lateral ventricle.

results showing no change in the percentage of BrdU/ Musashi1 or BrdU/ $\beta$ III-tubulin co-labeling between postischemic and control SVZa (Tonchev et al., 2005). Altogether, our findings suggest that ischemia increases the progenitor cell proliferation and absolute numbers without affecting progenitor differentiation, and in particular neuronal differentiation.

Despite the decrease of progenitors in SVZa over time, a significant proportion of these cells remained in SVZa for at least three months after ischemia (Tonchev et al., 2005). Immunophenotype analysis of these sustained cells revealed two distinct cell populations, each with a characteristic transcription factor expression pattern at protein level (Fig. 8B). The segregation of transcriptional regulators expressed by adult monkey neural or neuronal progenitors (Fig. 8B) suggests that a set of transcription factors might define a specific cell phenotype, similarly to the developing brain. Notably, the localization of some of the examined factors in either neuronal ( $\beta$ III-tubulin $\left.{ }^{+}\right)$or neural $\left(\right.$ Musashi $1^{+}$) precursors was not strictly selective as cells positive for Dlx1,5, Ngn1, Nkx2.2 or Olig3 were co-labeled not only for $\beta$ III-tubulin, but also for Musashi1. At the same time, these cells were negative for Ki67 at long-term time- points, indicating that the Musashi $1^{+}$cells co-labeled for Dlx1,5, Ngn1, Nkx2.2 or Olig3 at long-term time points were non-mitotic cells. These could be quiescent progenitors not in active cell cycle at the time of animal perfusion. Accordingly, we have previously demonstrated that Musashi $1^{+} / \mathrm{GFAP}^{+}$ cells in SVZa are not in active cell cycle (Tonchev et al., 2005), and a GFAP-enriched cellular population is thought to contain neural stem cells in adult human SVZa (Sanai et al., 2004). The partly overlapping transcription factor expression between Musashi $1^{+}$and $\beta$ III-tubulin ${ }^{+}$progenitors might be due to common molecular mechanisms involved in their regulation and/or might result from a lineage relationship between these two cell types. Further experiments are needed to clarify whether any of these possibilities might be true.

Different from Dlx1,5, Ngn1, Nkx2.2 or Olig3, the transcription factor Sox 1 co-stained exclusively with $\beta$ III-tubulin. While the high Sox1/ $\beta$ III-tubulin co-labeling is consistent with high Sox1/BrdU and BrdU/ $\beta$ III-tubulin co-labeling (Tonchev et al., 2005) at long-term time points, the relatively high percentage of $\mathrm{BrdU}^{+}$cells co-stained for Sox1 (about 50\%) at the short-term (day 9) time-point with concomitant minimal Sox1/Musashi1 co-staining $(<3 \%)$ is dis- 

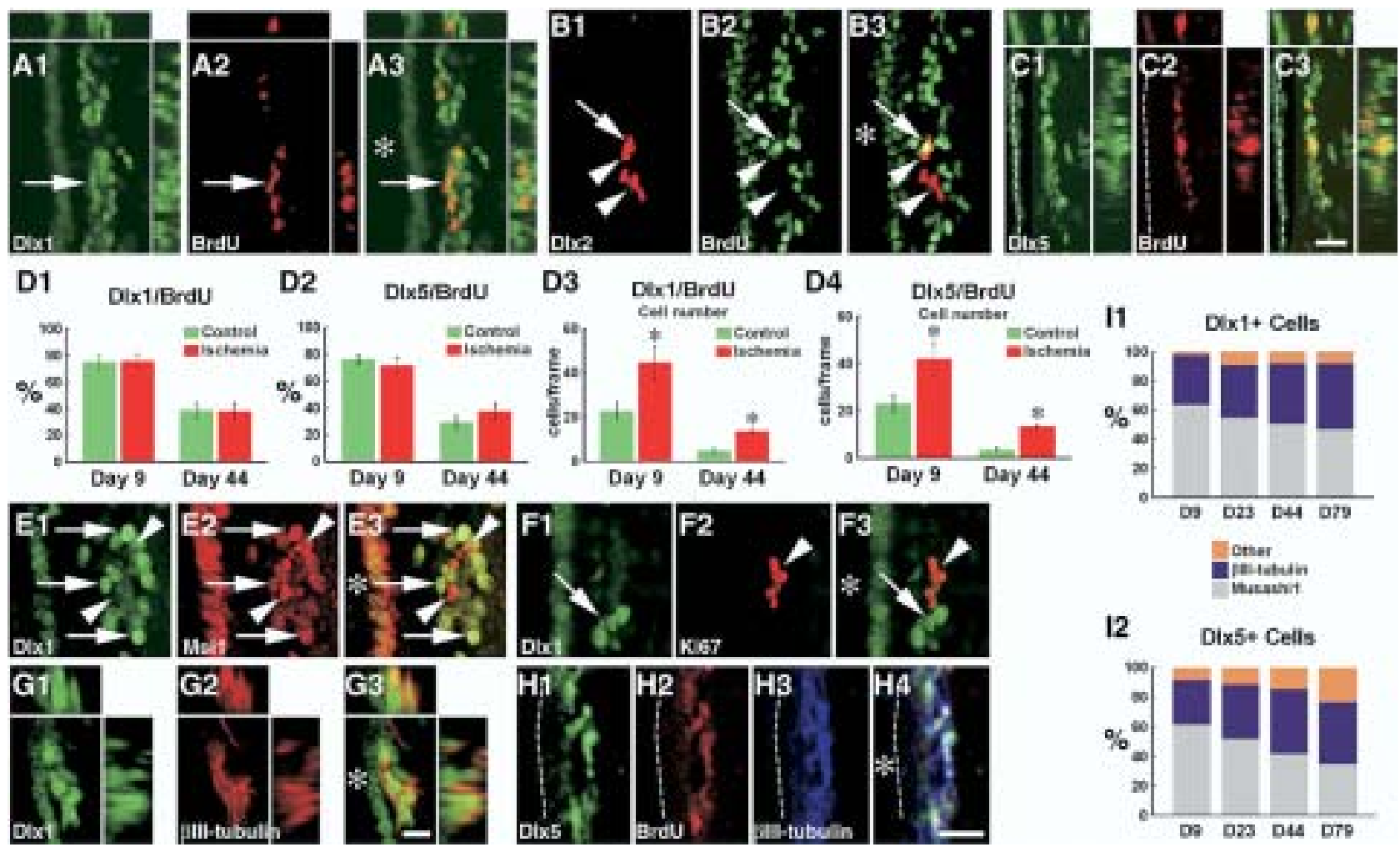

Fig. 6. Expression of Dlx proteins by SVZa progenitor cells. (A) Double-staining for Dlx1 (A1) and BrdU (A2), and overlay (A3), on day 9. A double-positive cluster is depicted (arrow). (B) Double-staining for Dlx2 (B1) and BrdU (B2), and overlay (B3), on day 9. Note that Dlx2 ${ }^{+}$cells (arrows) do not co-label with BrdU (arrowheads). (C) Double-staining for Dlx5 (C1) and BrdU (C2), and overlay (C3), on day 9. (D) Percentages (D1, D2) and absolute numbers (D3, D4) of $\mathrm{BrdU}^{+} / \mathrm{Dlx} 1^{+}(\mathrm{D} 1, \mathrm{D} 3)$ and $\mathrm{BrdU}^{+} / \mathrm{Dl} \times 5^{+}$(D2, D4) cells. * $P<0.05$ versus control. (E) Double-staining for Dlx1 (E1) and Musashi1 (Msi1, E2), and overlay (E3), on day 9. Note double-positive cells (e.g. arrows), and Dlx1-/Musashi1 ${ }^{+}$cells exhibiting mitotic figures (arrowheads), entangled in a cluster. (F) Double-staining for Dlx1 (F1, arrows) and Ki67 (F2, arrowheads), and overlay (F3), on day 44. (G) Double-staining for DIx1 (G1) and $\beta$ III-tubulin (G2), and overlay (G3), on day 79 . The Dlx $1^{+}$cluster is co-stained by $\beta$ III-tubulin. (H) Triple-staining for DIx5 (H1), BrdU (H2) and $\beta$ III-tubulin (H3), and overlay $(\mathrm{H} 4)$, on day 44. Note co-labeling in (ependymal layer is outlined by a dotted line). (I)

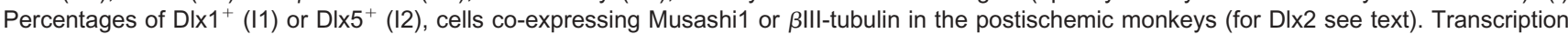
factor-positive cells that were Musashi $1^{-} / \beta$ III-tubulin ${ }^{-}$are designated "other." Percentages in the control monkeys did not differ significantly from the postischemic ones. Scale bar $=20 \mu \mathrm{m}(\mathrm{A}-\mathrm{C}, \mathrm{H}) ; 10 \mu \mathrm{m}(\mathrm{E}-\mathrm{G})$. Asterisk, lateral ventricle.

cordant with the high BrdU/Musashi1 co-expression characteristic for day 9 (Tonchev et al., 2005). The following cell phenotypes could be $\mathrm{BrdU}^{+} / \mathrm{Sox} 1^{+} /$Musashi1 $1^{-}$cells on day 9: $(i)$ the nearly $30 \%$ of the $\mathrm{BrdU}^{+}$cells negative for Musashi1 on day 9 (Tonchev et al., 2005), and (ii) the approximately $10 \%$ of the Sox $1^{+}$cells with an unidentified (non- $\beta$ III-tubulin/non-Musashi1) phenotype as shown in the present study. Moreover, the finding of cells stained for transcription factors but negative for either $\beta$ III-tubulin or Musashi1 suggests phenotypical heterogeneity, a feature that is observed in multipotent progenitor cells (Pevny and Rao, 2003).

Non-primate mammalian models are essential in addressing fundamental stem cell issues. At the same time, primates appear to exhibit considerably lower levels of neurogenesis than non-primate mammals at both normal conditions (Kornack and Rakic, 1999) or in a context of injury-enhanced neurogenic response (Tonchev et al., 2003). The framework of molecular signals that may underlie this interspecies discrepancy is currently unknown. We observed certain similarities between our results in monkeys and studies using nonprimate models with respect to transcription factor expression by adult SVZa progenitors. In particular, Emx2 and Sox2,3 were expressed by actively dividing sustained progenitors in monkey SVZa consistent with their previously reported expression in early multipotent progenitor/stem cells (Galli et al., 2002; Bylund et al., 2003; Graham et al., 2003; Ferri et al., 2004; Komitova and Eriksson, 2004), while Sox1 (but not Sox2,3) protein was predominantly localized in monkey neuronal progenitors consistent with its previously reported activity inducing neuronal commitment (Kan et al., 2004). At the same time, we noticed the following discrepancies between our results in monkeys and studies using nonprimate animal models. First, Pax6 appeared to be predominantly localized to neuronal progenitors in adult mouse SVZa (Hack et al., 2004), while in monkey SVZa Pax6 was mainly positive in neural progenitors. Second, the transcription factors DIx2 and Olig2 label transitamplifying precursors in adult rodent SVZa (Doetsch et al., 2002; Hack et al., 2004) which are highly prolifera- 


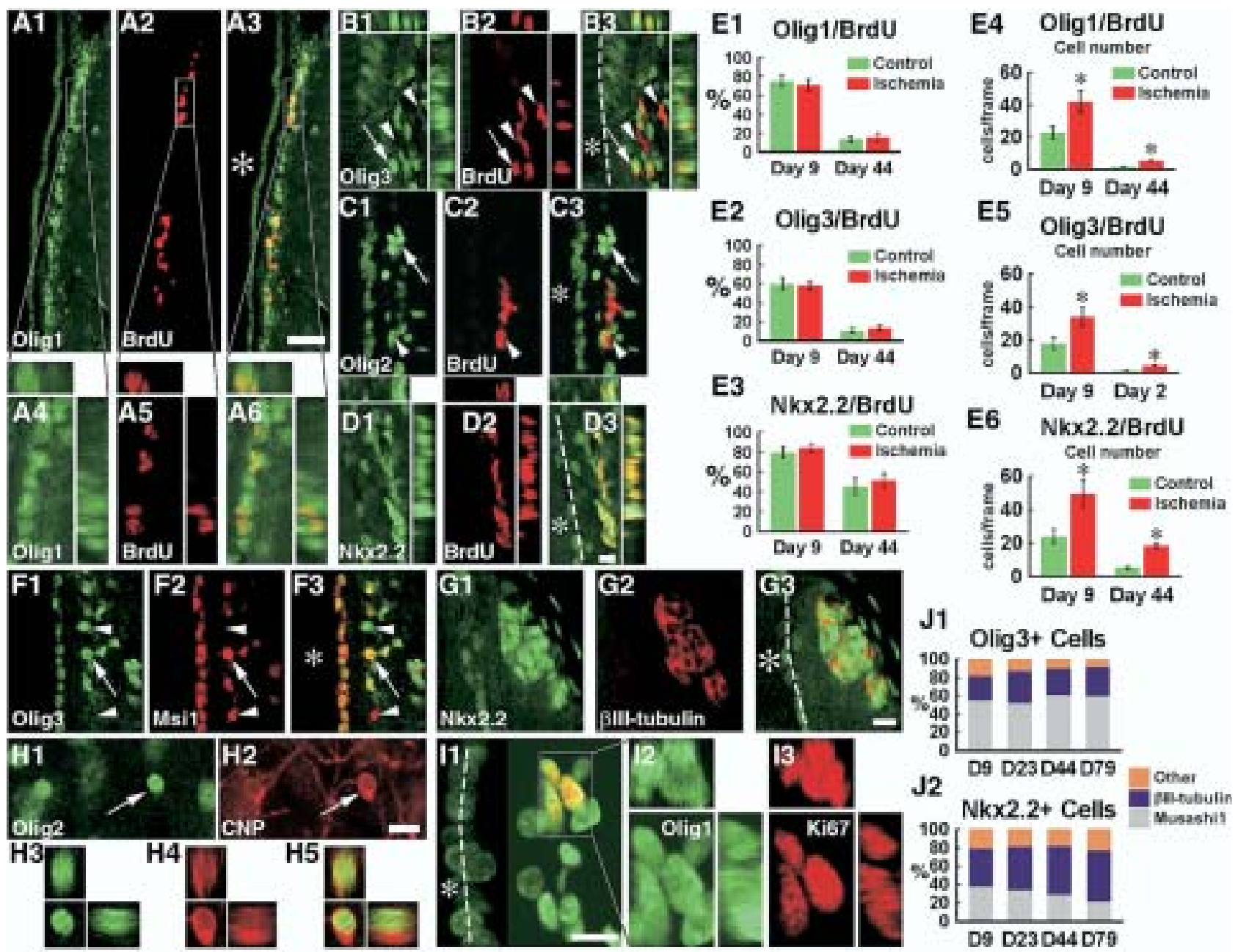

Fig. 7. Expression of Olig proteins and Nkx2.2 by SVZa progenitor cells. (A) Double-staining for Olig1 (A1) and BrdU (A2), and overlay (A3), on day 9. The region depicted by a box is magnified in A4-A6 with orthogonal projections. (B) Double-staining for Olig3 (B1) and BrdU (B2), and overlay (B3) on day 44. Several $\mathrm{BrdU}^{+}$cells are Olig3 ${ }^{-}$(arrowheads). A double-positive cell is depicted by arrows. (C) Double-staining for Olig2 (C1) and BrdU (C2), and overlay (C3), on day 9. A cluster positive for Olig2 (arrows) is not co-labeled by BrdU. A single cell in a neighboring BrdU ${ }^{+}$cluster is weakly positive for Olig2 (arrowheads). (D) Double-staining for Nkx2.2 (D1) and BrdU (D2), and overlay (D3), on day 9. Most cells are double-positive. (E) Percentages (E1-E3) and absolute numbers (E4-E6) of BrdU ${ }^{+} / \mathrm{Olig} 1^{+}(\mathrm{E} 1, \mathrm{E} 4), \mathrm{BrdU}^{+} / \mathrm{Olig} 3^{+}$(E2, E5) and Nkx2.2 (E3, E6). * $P<0.05$ versus control. (F) Double-staining for Olig3 (F1) and Musashi1 (Msi1, F2), and overlay (F3), on day 9 (representative also for Olig1 and Nkx2.2). Double-labeled cells are depicted by arrows, while single-labeled cells (either Olig $3^{+} /$Musashi $^{-}$or Olig3 ${ }^{-} /$Musashi $^{+}{ }^{+}$) are depicted by arrowheads. (G) Double-staining for Nkx2.2 (G1) and $\beta$ III-tubulin (G2), and overlay (G3), on day 23 (representative also for Olig3). (H) Staining for Olig2 (H1) and CNP (H2), on day 79. Two $\mathrm{CNP}^{+}$oligodendrocytes are co-labeled by Olig2. The cell depicted by an arrow is shown in a three-dimensional view with color separation in H3 (Olig2), H4 (CNP) and H5 (overlay). The image is representative also for Nkx2.2. (I) Double-staining for Olig1 (I1) and Ki67 (I2), on day 44 . The cluster depicted by a box is magnified in 12 and 13 with color separation and orthogonal projections. (J) Percentages of Olig $3^{+}(\mathrm{J} 1)$ or Nkx2.2 $2^{+}(\mathrm{J} 2)$, cells co-expressing Musashi1 or $\beta$ Ill-tubulin in the postischemic monkeys (for Olig1,2 see text). Transcription factor-positive cells that were Musashi1 ${ }^{-} / \beta / I$-tubulin ${ }^{-}$are designated "other." Percentages in the control monkeys did not differ significantly from the postischemic ones. Scale bar $=50 \mu \mathrm{m}(\mathrm{A}) ; 10 \mu \mathrm{m}(\mathrm{B}-\mathrm{I})$. Asterisk, lateral ventricle.

tive (Doetsch et al., 1997), while in our experiments we found very few $\mathrm{BrdU}^{+} / \mathrm{DIx} 2^{+}$or $\mathrm{BrdU}^{+} / \mathrm{Olig}^{+}$cells. This suggests that monkey SVZa niche either has very few type $C$ cells or that these cells do not express DIx2 and Olig2. A detailed characterization of the cellular composition of adult monkey SVZa as done in rodents (Doetsch et al., 1997) is necessary to confirm or put aside this speculation.

The decision whether monkey SVZa progenitors will preserve their localization in the niche or will migrate away from SVZa might be coordinated by a balance of factors promoting or inhibiting proliferation and migration. Such putative factors are the neurotransmitters glutamate and GABA, which exhibit either stimulatory or inhibitory effects on the proliferation of embryonic precursor cells from ventricular zone or SVZ, respectively (Haydar et al., 2000). This suggests that distinct precursor cell populations respond to glutamate/GABA in different ways. In adult SVZa, glutamate and GABA have been reported to exert opposing effects on progenitor cells: glutamate activates (Brazel et al., 2005) while GABA inhibits (Liu et al., 2005) their proliferation. There- 
A

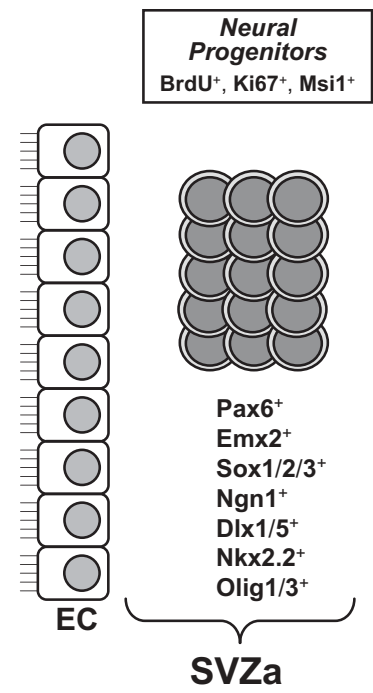

B

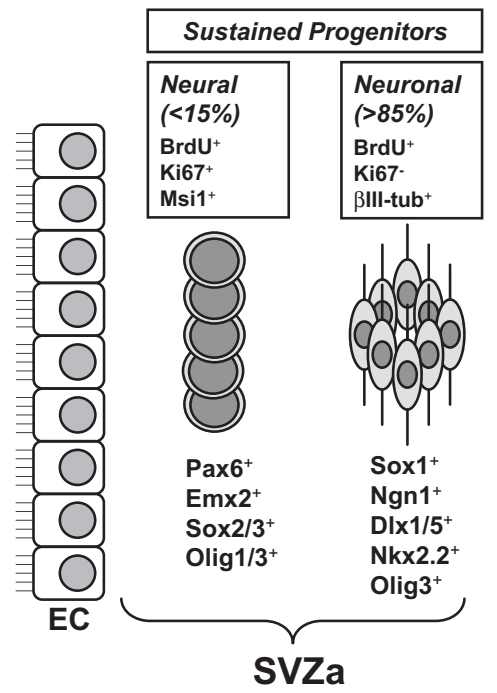

Fig. 8. Schematic summary of transcription factor protein expression by monkey SVZa progenitor cells in the short-term (A) or long-term (B) survival time-points after ischemia. (A) On day 9 the BrdU ${ }^{+}$cells are predominantly positive for Musashi1 and Ki67 (Tonchev et al., 2005 ). These cells expressed a large number of the transcription factors investigated in this study (Ngn2, DIx2 and Olig2 were omitted from the scheme because of the minimal proportion of co-labeling with BrdU; a small fraction of BrdU ${ }^{+} / \beta$ III-tubulin ${ }^{+}$cells at this time point were also skipped for clarity). (B) At long-term after ischemia, the sustained BrdU ${ }^{+}$cells are either Musashi $1^{+} / \mathrm{Ki}^{+} 7^{+}$(up to $15 \%$ of the $\mathrm{BrdU}^{+}$cells) or $\beta I I I-t u b u l i n+/ \mathrm{Ki}^{-} 7^{-}$(over $85 \%$ of the $\mathrm{BrdU}^{+}$ cells) (Tonchev et al., 2005), and these two distinct cell phenotypes expressed distinct sets of transcription factor proteins. The sustained cells in active cell cycle $\left(\mathrm{Ki}_{6} 7^{+}\right)$preferentially expressed markers for early stem/progenitor cells (Emx2, Pax6, Sox2,3), while sustained cells that have exited active cell cycle $\left(\mathrm{Ki}_{67^{-}}\right.$) were preferentially positive for region-specific proteins with pro-neuronal actions (Sox1, Dlx1,5, Ngn1, Nkx2.2). Note that Sox1, Ngn1, Dlx1,5, Nkx2.2 and Olig3 proteins were expressed also by some Musashi1 ${ }^{+}$cells (see text for details), which is not depicted on the scheme, for clarity. EC, ependymal cells; Msi1, Musashi1; $\beta$ III-tub, $\beta$ III-tubulin.

fore, it is possible to speculate that these two endogenous amino acids may differentially affect neural or neuronal progenitors in monkey SVZa to achieve precursor cell proliferation/differentiation with either retention in SVZa or migration toward the olfactory bulb. Other extracellular signaling molecules might also be involved in precursor cell modulation by affecting transcription factor activity. For example, Ngn1 is required for erythropoietin-enhanced neurogenesis (Wang et al., 2006).

The present study had not aimed at deciphering the mechanisms for differential expression of transcription factors by neural progenitors with different proliferation or migration activities. Such mechanisms possibly include modulatory effects at promoter and/or enhancer regions of various transcription factors. For example, two distinct Sox2 enhancers are active in multipotent neural progenitors but cease to function in differentiated cells (Zappone et al., 2000; Miyagi et al., 2004). The mouse Pax6 gene has three promoters under the control of at least six different enhancers, directing Pax6 expression in distinct tissues (reviewed by Morgan, 2004). Given that different tissues, and even different progenitor cell types, require activation of selective regulatory elements, one may speculate that ischemia could differentially activate such elements in sustained or migrating SVZa progenitors. Unraveling the transcriptional network involved in the regulation of adult progenitor cell specification may lead to development of more effective strategies to direct these cells to adopt a selective cellular phenotype required in a specific brain lesion.
Acknowledgments-We thank Hirohide Takebayashi for the antiOlig2 antibody and George N. Chaldakov for valuable discussions. The Japanese Ministries of Education, Culture, Sports, Science and Technology (Kiban B: 15390432) and Health, Labor and Welfare (H15-Kokoro-018), and the Bulgarian Ministry of Education and Science (L1311/03) supported this work.

\section{REFERENCES}

Alvarez-Buylla A, Lim DA (2004) For the long run: maintaining germinal niches in the adult brain. Neuron 41:683-686.

Anderson SA, Qiu M, Bulfone A, Eisenstat DD, Meneses J, Pedersen $R$, Rubenstein JL (1997) Mutations of the homeobox genes Dlx-1 and DIx-2 disrupt the striatal subventricular zone and differentiation of late born striatal neurons. Neuron 19:27-37.

Arvidsson A, Collin T, Kirik D, Kokaia Z, Lindvall O (2002) Neuronal replacement from endogenous precursors in the adult brain after stroke. Nat Med 8:963-970.

Braun PE, Sandillon F, Edwards A, Matthieu JM, Privat A (1988) Immunocytochemical localization by electron microscopy of $2^{\prime} 3^{\prime}$ cyclic nucleotide $3^{\prime}$-phosphodiesterase in developing oligodendrocytes of normal and mutant brain. J Neurosci 8:3057-3066.

Brazel CY, Nunez JL, Yang Z, Levison SW (2005) Glutamate enhances survival and proliferation of neural progenitors derived from the subventricular zone. Neuroscience 131:55-65.

Bylund M, Andersson E, Novitch BG, Muhr J (2003) Vertebrate neurogenesis is counteracted by Sox $1-3$ activity. Nat Neurosci 6:1162-1168.

Doetsch F, Garcia-Verdugo JM, Alvarez-Buylla A (1997) Cellular composition and three-dimensional organization of the subventricular germinal zone in the adult mammalian brain. J Neurosci 17 : 5046-5061. 
Doetsch F, Petreanu L, Caille I, Garcia-Verdugo JM, Alvarez-Buylla A (2002) EGF converts transit-amplifying neurogenic precursors in the adult brain into multipotent stem cells. Neuron 36:1021-1034.

Eriksson PS, Perfilieva E, Bjork-Eriksson T, Alborn AM, Nordborg C, Peterson DA, Gage FH (1998) Neurogenesis in the adult human hippocampus. Nat Med 4:1313-1317.

Fancy SP, Zhao C, Franklin RJ (2004) Increased expression of Nkx2.2 and Olig2 identifies reactive oligodendrocyte progenitor cells responding to demyelination in the adult CNS. Mol Cell Neurosci 27:247-254.

Ferri AL, Cavallaro M, Braida D, Di Cristofano A, Canta A, Vezzani A, Ottolenghi S, Pandolfi PP, Sala M, DeBiasi S, Nicolis SK (2004) Sox2 deficiency causes neurodegeneration and impaired neurogenesis in the adult mouse brain. Development 131:3805-3819.

Gage FH (2000) Mammalian neural stem cells. Science 287:14331438.

Galli R, Fiocco R, De Filippis L, Muzio L, Gritti A, Mercurio S, Broccoli $V$, Pellegrini M, Mallamaci A, Vescovi AL (2002) Emx2 regulates the proliferation of stem cells of the adult mammalian central nervous system. Development 129:1633-1644.

Gleeson JG, Lin PT, Flanagan LA, Walsh CA (1999) Doublecortin is a microtubule-associated protein and is expressed widely by migrating neurons. Neuron 23:257-271.

Gotz M (2003) Glial cells generate neurons-master control within CNS regions: developmental perspectives on neural stem cells. Neuroscientist 9:379-397.

Graham V, Khudyakov J, Ellis P, Pevny L (2003) SOX2 functions to maintain neural progenitor identity. Neuron 39:749-765.

Hack MA, Sugimori M, Lundberg C, Nakafuku M, Gotz M (2004) Regionalization and fate specification in neurospheres: the role of Olig2 and Pax6. Mol Cell Neurosci 25:664-678.

Haydar TF, Wang F, Schwartz ML, Rakic P (2000) Differential modulation of proliferation in the neocortical ventricular and subventricular zones. J Neurosci 20:5764-5774.

Heins N, Cremisi F, Malatesta P, Gangemi RM, Corte G, Price J, Goudreau G, Gruss P, Gotz M (2001) Emx2 promotes symmetric cell divisions and a multipotential fate in precursors from the cerebral cortex. Mol Cell Neurosci 18:485-502.

Heins N, Malatesta P, Cecconi F, Nakafuku M, Tucker KL, Hack MA, Chapouton P, Barde YA, Gotz M (2002) Glial cells generate neurons: the role of the transcription factor Pax6. Nat Neurosci 5:308-315

Iwai M, Sato K, Kamada H, Omori N, Nagano I, Shoji M, Abe K (2003) Temporal profile of stem cell division, migration, and differentiation from subventricular zone to olfactory bulb after transient forebrain ischemia in gerbils. J Cereb Blood Flow Metab 23:331-341.

Jin K, Minami M, Lan JQ, Mao XO, Batteur S, Simon RP, Greenberg DA (2001) Neurogenesis in dentate subgranular zone and rostral subventricular zone after focal cerebral ischemia in the rat. Proc Natl Acad Sci U S A 98:4710-4715.

Kan L, Israsena N, Zhang Z, Hu M, Zhao LR, Jalali A, Sahni V, Kessler JA (2004) Sox1 acts through multiple independent pathways to promote neurogenesis. Dev Biol 269:580-594.

Kaneko Y, Sakakibara S, Imai T, Suzuki A, Nakamura Y, Sawamoto K, Ogawa Y, Toyama Y, Miyata T, Okano H (2000) Musashi1: an evolutionally conserved marker for CNS progenitor cells including neural stem cells. Dev Neurosci 22:139-153.

Komitova M, Eriksson PS (2004) Sox-2 is expressed by neural progenitors and astroglia in the adult rat brain. Neurosci Lett 369: $24-27$.

Kornack DR, Rakic P (1999) Continuation of neurogenesis in the hippocampus of the adult macaque monkey. Proc Natl Acad Sci U S A 96:5768-5773.

Kornack DR, Rakic P (2001) The generation, migration, and differentiation of olfactory neurons in the adult primate brain. Proc Natl Acad Sci U S A 98:4752-4757.

Letinic K, Zoncu R, Rakic P (2002) Origin of GABAergic neurons in the human neocortex. Nature 417:645-649.
Liu X, Wang Q, Haydar TF, Bordey A (2005) Nonsynaptic GABA signaling in postnatal subventricular zone controls proliferation of GFAP-expressing progenitors. Nat Neurosci 8:1179-1187.

Miyagi S, Saito T, Mizutani K, Masuyama N, Gotoh Y, Iwama A, Nakauchi H, Masui S, Niwa H, Nishimoto M, Muramatsu M, Okuda A (2004) The Sox-2 regulatory regions display their activities in two distinct types of multipotent stem cells. Mol Cell Biol 24: 4207-4220.

Monuki ES, Walsh CA (2001) Mechanisms of cerebral cortical patterning in mice and humans. Nat Neurosci 4(Suppl):1199-1206.

Morgan R (2004) Conservation of sequence and function in the Pax6 regulatory elements. Trends Genet 20:283-287.

Muzio L, DiBenedetto B, Stoykova A, Boncinelli E, Gruss P, Mallamaci A (2002) Conversion of cerebral cortex into basal ganglia in Emx2(-/-) Pax6(Sey/Sey) double-mutant mice. Nat Neurosci $5: 737-745$.

Okano H (2002) The stem cell biology of the central nervous system. J Neurosci Res 69:698-707.

Ourednik V, Ourednik J, Flax JD, Zawada WM, Hutt C, Yang C, Park KI, Kim SU, Sidman RL, Freed CR, Snyder EY (2001) Segregation of human neural stem cells in the developing primate forebrain. Science 293:1820-1824.

Parent JM, Vexler ZS, Gong C, Derugin N, Ferriero DM (2002) Rat forebrain neurogenesis and striatal neuron replacement after focal stroke. Ann Neurol 52:802-813.

Pencea V, Bingaman KD, Freedman LJ, Luskin MB (2001) Neurogenesis in the subventricular zone and rostral migratory stream of the neonatal and adult primate forebrain. Exp Neurol 172:1-16.

Perera M, Merlo GR, Verardo S, Paleari L, Corte G, Levi G (2004) Defective neuronogenesis in the absence of Dlx5. Mol Cell Neurosci 25:153-161.

Pevny L, Rao MS (2003) The stem-cell menagerie. Trends Neurosci 26:351-359.

Pincus DW, Keyoung HM, Harrison-Restelli C, Goodman RR, Fraser RA, Edgar M, Sakakibara S, Okano H, Nedergaard M, Goldman SA (1998) Fibroblast growth factor-2/brain-derived neurotrophic factor-associated maturation of new neurons generated from adult human subependymal cells. Ann Neurol 43:576-585.

Rowitch DH (2004) Glial specification in the vertebrate neural tube. Nat Rev Neurosci 5:409-419.

Roy NS, Benraiss A, Wang S, Fraser RA, Goodman R, Couldwell WT, Nedergaard M, Kawaguchi A, Okano H, Goldman SA (2000) Promoter-targeted selection and isolation of neural progenitor cells from the adult human ventricular zone. J Neurosci Res 59:321331.

Sakakibara S, Imai T, Hamaguchi K, Okabe M, Aruga J, Nakajima K, Yasutomi D, Nagata T, Kurihara Y, Uesugi S, Miyata T, Ogawa M, Mikoshiba K, Okano H (1996) Mouse-Musashi-1, a neural RNAbinding protein highly enriched in the mammalian CNS stem cell. Dev Biol 176:230-242.

Sakakibara S, Okano H (1997) Expression of neural RNA-binding proteins in the postnatal CNS: implications of their roles in neuronal and glial cell development. J Neurosci 17:8300-8312.

Sanai N, Tramontin AD, Quinones-Hinojosa A, Barbaro NM, Gupta N, Kunwar S, Lawton MT, McDermott MW, Parsa AT, Manuel-Garcia Verdugo J, Berger MS, Alvarez-Buylla A (2004) Unique astrocyte ribbon in adult human brain contains neural stem cells but lacks chain migration. Nature 427:740-744.

Schuurmans C, Guillemot F (2002) Molecular mechanisms underlying cell fate specification in the developing telencephalon. Curr Opin Neurobiol 12:26-34.

Schuurmans C, Armant O, Nieto M, Stenman JM, Britz O, Klenin N, Brown C, Langevin LM, Seibt J, Tang H, Cunningham JM, Dyck R, Walsh C, Campbell K, Polleux F, Guillemot F (2004) Sequential phases of cortical specification involve Neurogenin-dependent and -independent pathways. EMBO J 23:2892-2902.

Shirasaki R, Pfaff SL (2002) Transcriptional codes and the control of neuronal identity. Annu Rev Neurosci 25:251-281. 
Stenman J, Toresson H, Campbell K (2003) Identification of two distinct progenitor populations in the lateral ganglionic eminence: implications for striatal and olfactory bulb neurogenesis. J Neurosci 23:167-174.

Tonchev AB, Yamashima T, Zhao L, Okano HJ, Okano H (2003) Proliferation of neural and neuronal progenitors after global brain ischemia in young adult macaque monkeys. Mol Cell Neurosci 23:292-301.

Tonchev AB, Yamashima T, Sawamoto K, Okano H (2005) Enhanced proliferation of progenitor cells in the subventricular zone and limited neuronal production in the striatum and neocortex of adult macaque monkeys after global cerebral ischemia. J Neurosci Res 81:776-788.

Wang L, Zhang ZG, Zhang RL, Jiao ZX, Wang Y, Pourabdollah-Nejad DS, Letourneau Y, Gregg SR, Chopp M (2006) Neurogenin 1 mediates erythropoietin enhanced differentiation of adult neural progenitor cells. J Cereb Blood Flow Metab [Epub ahead of print] doi: 10.1038/sj.jcbfm.9600215.
Yamashima T, Kohda Y, Tsuchiya K, Ueno T, Yamashita J, Yoshioka T, Kominami E (1998) Inhibition of ischaemic hippocampal neuronal death in primates with cathepsin B inhibitor CA-074: a novel strategy for neuroprotection based on 'calpain-cathepsin hypothesis. ' Eur J Neurosci 10:1723-1733.

Yamashima T (2000) Implication of cysteine proteases calpain, cathepsin and caspase in ischemic neuronal death of primates. Prog Neurobiol 62:273-295.

Zappone MV, Galli R, Catena R, Meani N, De Biasi S, Mattei E, Tiveron C, Vescovi AL, Lovell-Badge R, Ottolenghi S, Nicolis SK (2000) Sox2 regulatory sequences direct expression of a (beta)geo transgene to telencephalic neural stem cells and precursors of the mouse embryo, revealing regionalization of gene expression in CNS stem cells. Development 127:2367-2382.

Zhang RL, Zhang ZG, Zhang L, Chopp M (2001) Proliferation and differentiation of progenitor cells in the cortex and the subventricular zone in the adult rat after focal cerebral ischemia. Neuroscience 105:33-41. 